\title{
Spatial patterns of bacterial abundance, activity and community composition in relation to water masses in the eastern Mediterranean Sea
}

\author{
Taichi Yokokawa ${ }^{1, *}$, Daniele De Corte $^{1,2}$, Eva Sintes $^{3}$, Gerhard J. Herndl ${ }^{1,3}$ \\ ${ }^{1}$ Department of Biological Oceanography, Royal Netherlands Institute for Sea Research (NIOZ), PO Box 59, 1790 AB, \\ Den Burg, The Netherlands \\ ${ }^{2}$ Center for Ecological and Evolutionary Studies, University of Groningen, PO Box 14, 9750 AA Haren, The Netherlands \\ ${ }^{3}$ University of Vienna, Department of Marine Biology, Faculty Center of Ecology, Althanstrasse 14, 1090 Vienna, Austria
}

\begin{abstract}
To determine the variation of bacterial activity and community composition between and within specific water masses, samples were collected throughout the water column at 5 stations in the eastern Mediterranean Sea corresponding to the regions of the northern Aegean, mid-Aegean, western Cretan, Ionian and southern Aegean Seas. Prokaryotic abundance below $100 \mathrm{~m}$ declined with depth at all the stations, while decreasing trends with depth in prokaryotic heterotrophic activity were present only at 2 out of the 5 stations. Bacterial community composition (BCC), determined using both automated rRNA intergenic spacer analysis and terminal-restriction-fragment length polymorphism, was also related to depth although the number of operational taxonomic units was remarkably constant throughout the water column. Overall, the maximums in similarity values of the BCC between water sample pairs decreased with increasing temperature-salinity (T-S) distance of the water samples probably due to distinct biogeochemical characteristics of water masses. However, considerable dissimilarity in the BCC between samples with identical T-S values, and hence within the same water mass, was also observed, possibly reflecting heterogeneity in the organic matter field or in biotic control within a given water body. Thus, we conclude that the richness of bacterial communities is remarkably constant with depth down to bathypelagic waters. The similarity of bacterial communities in water parcels with identical temperature and salinity can range from highly similar to very dissimilar, reflecting variability in substrate supply despite the physical uniformity of water parcels.
\end{abstract}

KEY WORDS: Bacteria $\cdot$ Community composition $\cdot$ Patchiness $\cdot$ Spatial scale $\cdot$ Eastern Mediterranean Sea Resale or republication not permitted without written consent of the publisher

\section{INTRODUCTION}

Prokaryotes play a major role in marine biogeochemical fluxes (Williams 2000). The relation between microbially mediated biogeochemical transformation rates and the prokaryotic community composition is a central research topic in microbial ecology, linked to the function-stability debate (Miki et al. 2008, Fuhrman 2009, Yokokawa \& Nagata 2010). Examining distribution patterns of prokaryotes and environmental parameters over space and time is one of the ap- proaches used to determine how prokaryotes relate to specific biogeochemical processes.

The distribution patterns of prokaryotic abundance and activity throughout the water column of the open ocean have been determined extensively in the Atlantic (Herndl et al. 2005, Reinthaler et al. 2006), in the North Pacific (Nagata et al. 2000), in the Arabian Sea (Hansell \& Ducklow 2003) and in the north-western Mediterranean Sea (Tanaka \& Rassoulzadegan 2004, Winter et al. 2009). Also, at the 2 open ocean long-term time-series stations, the Bermuda Atlantic 
Time-Series Study and the Hawaii Ocean Time-Series, microbial activity and community dynamics have been related. From these data, the notion emerged that the prokaryotic community composition of the open oceanic water column is highly stratified (Giovannoni et al. 1996, DeLong et al. 2006). Distinct depth profiles of prokaryotes have been found for community composition and specific phylogenetic groups. For example, Crenarchaea are the dominant group in deep waters (Herndl et al. 2005, De Corte et al. 2009). The SAR 202 cluster dominates in waters below $2000 \mathrm{~m}$ depth, comprising up to $40 \%$ of the bacterial community in the North Atlantic (Varela et al. 2008).

The eastern Mediterranean Sea features several characteristics, which affect prokaryotic activity and probably community composition, such as its oligotrophic nature and the warm deep waters (about $14^{\circ} \mathrm{C}$ ). In the North Aegean Sea, Black Sea Water (BSW) forms the surface waters. Below the BSW, Levantine Intermediate Water (LIW) extends to about $400 \mathrm{~m}$ depth, and North Aegean Deep Water (NAeDW) reaches down to the bottom of the North Aegean Trough. In the mid-Aegean Sea, surface waters are comprised by Levantine Surface Water (LSW) followed by LIW, and NAeDW down to the bottom of the Chios Basin. In the South Aegean Sea, the main water masses are the surface Atlantic Water (AW), LIW, Transitional Mediterranean Water mass (TMW) and the Cretan Deep Water (CDW) in the Cretan Basin. In the Ionian Sea, the water masses from surface to bottom waters are AW, LIW, TMW and the East Mediterranean Deep Water mass (EMDW). All the water masses have a specific temperature and salinity signature, although the water masses are composed of waters of different ages (Zervakis et al. 2000). In the layer up to $400 \mathrm{~m}$ depth, BSW, LIW, LSW, AW and TMW mix frequently on a seasonal time scale. In contrast, the deep waters (NAeDW, CDW) in the basins of the eastern Mediterranean Sea are fairly isolated and exchange on a decadal scale (Zervakis et al. 2004).

There are only a few studies on the prokaryotic community composition of the water column of the eastern Mediterranean Sea using terminal-restriction-fragment length polymorphism (T-RFLP) (Moeseneder et al. 2001a,b), clone libraries (Moeseneder et al. 2005) and fosmid libraries (Martín-Cuadrado et al. 2007). The differences in the characteristics of the water bodies from north to south in the eastern Mediterranean Sea are reflected by the considerable changes in the $\mathrm{BCC}$ (Moeseneder et al. 2001a) and microbial activity (De Corte et al. 2009).

The aim of the present study was to determine the spatial patterns of prokaryotic abundance, activity and BCC in the different water masses of the eastern Mediterranean Sea. Specifically, we assessed spatial variations of the $\mathrm{BCC}$ in relation to the specific water masses identified by their temperature and salinity characteristics.

\section{MATERIALS AND METHODS}

Study site and sampling. The POSEIDON cruise was conducted with the RV 'AEGAEO' (Hellenic Center for Marine Research, Greece) in the eastern Mediterranean Sea in May 2007 and sampled 5 stations (Fig. 1). The stations were located in the North Aegean $\left(48^{\circ} 7.0^{\prime} \mathrm{N}, 24^{\circ} 32.5^{\prime} \mathrm{E}\right)$, mid-Aegean $\left(37^{\circ} 42.1^{\prime} \mathrm{N}\right.$, $\left.25^{\circ} 26.0^{\prime} \mathrm{E}\right)$, western Cretan $\left(36^{\circ} 13.2^{\prime} \mathrm{N}, 23^{\circ} 18.3^{\prime} \mathrm{E}\right)$, Ionian (36 $\left.15.9^{\prime} \mathrm{N}, 21^{\circ} 30.1^{\prime} \mathrm{E}\right)$ and South Aegean Seas $\left(35^{\circ} 47.2^{\prime} \mathrm{N}, 24^{\circ} 54.7^{\prime} \mathrm{E}\right)$. Water samples were obtained from surface waters (10 $\mathrm{m}$ depth) and the meso- (150 to $1000 \mathrm{~m}$ depth) and bathypelagic layers (1000 to $4350 \mathrm{~m}$ depth) with 51 Niskin bottles mounted on a CTD rosette sampler.

Abundance of prokaryotes. Prokaryotic abundance was determined in seawater collected from the Niskin bottles and fixed with $0.2 \mu \mathrm{m}$ filtered formaldehyde ( $2 \%$ final concentration). Thereafter, the samples were frozen in liquid nitrogen for $10 \mathrm{~min}$ and kept at $-80^{\circ} \mathrm{C}$ until analysis. Prokaryotic abundance was determined by flow cytometry within 2 mo after collecting the samples. Samples were thawed to room temperature, and $0.5 \mathrm{ml}$ subsamples were stained with SYBR Green I in the dark for $10 \mathrm{~min}$, and, subsequently, $1 \mu \mathrm{m}$ fluorescent latex beads (Molecular Probes) $\left(\sim 10^{5} \mathrm{ml}^{-1}\right)$ were added to the samples as an internal standard. The

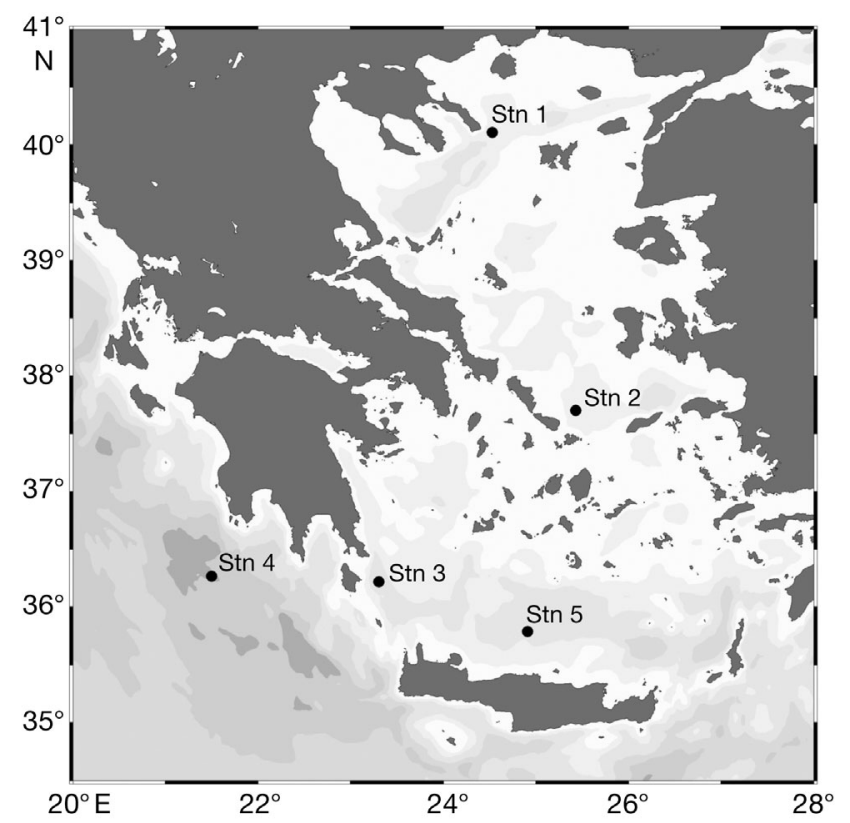

Fig. 1. Sites in the eastern Mediterranean Sea sampled during the POSEIDON cruise in May 2007 
prokaryotes were enumerated on a FACScalibur flow cytometer (Becton Dickinson) by their signature in a plot of green fluorescence versus side scatter, and the abundance was calculated based on the ratio of stained cells to the added bead standard.

Leucine incorporation rate. ${ }^{3} \mathrm{H}$-leucine incorporation rate was determined as a proxy for prokaryotic production (Kirchman 2001). Subsamples (5 to $40 \mathrm{ml}$ ) from each depth were amended with $5 \mathrm{nM}^{3} \mathrm{H}$-leucine (Amersham, specific activity $160 \mathrm{Ci} \mathrm{mmol}^{-1}$ ) and incubated at in situ temperature $\left( \pm 2^{\circ} \mathrm{C}\right)$ in the dark. Incubation time varied depending on depth: $1 \mathrm{~h}$ for upper waters (up to $100 \mathrm{~m}$ ) and $24 \mathrm{~h}$ for deep waters (below $100 \mathrm{~m})$. After incubation, samples were filtered onto polycarbonate filters (pore size, $0.2 \mu \mathrm{m}$; Millipore) and rinsed twice with both $5 \%$ trichloroacetic acid and $80 \%$ ethanol. The samples were radioassayed with a liquid scintillation counter (1211 Rack beta, Wallac) using FilterCount (Packard) as scintillation cocktail. Duplicate samples and 1 trichloroacetic acid-killed control were prepared for each depth. The disintegrations per minute (DPM) of the killed control were subtracted from the mean DPM of the corresponding duplicate samples and converted to leucine incorporation rates.

Bacterial community composition. A volume of $10 \mathrm{l}$ of seawater was filtered through a $0.22 \mu \mathrm{m}$ Sterivex filter cartridge (Millipore). Thereafter, $1.8 \mathrm{ml}$ of lysis buffer (40 mM EDTA, $50 \mathrm{mM}$ Tris-HCL, $0.75 \mathrm{M}$ sucrose) was added to the filter cartridge and stored at $-80^{\circ} \mathrm{C}$. DNA extraction from Sterivex filter cartridges was performed by Mega Kit extraction (MoBIO Laboratories) using the protocol of the manufacturer. DNA extracts were concentrated ( 10-fold) with a Centricon device (Millipore).

PCR and T-RFLP. PCR conditions and chemicals were applied as described by Moeseneder et al. (2001a). One microlitre of the DNA extract was used as a template in a $50 \mu \mathrm{l}$ PCR mixture. The primers used for PCR were the Bacteria-specific primer 27F-FAM and the universal primer 1492R-JOE (Lane 1991). Samples were amplified by an initial denaturation step at $94^{\circ} \mathrm{C}$ (3 min), followed by 35 cycles of denaturation at $94^{\circ} \mathrm{C}(1 \mathrm{~min})$, annealing at $55^{\circ} \mathrm{C}(1 \mathrm{~min})$ and extension at $72^{\circ} \mathrm{C}(1 \mathrm{~min})$. Cycling was completed by a final extension at $72^{\circ} \mathrm{C}$ ( $7 \mathrm{~min}$ ). Two negative controls ( $1 \mu \mathrm{l}$ of Sigma water and $49 \mu \mathrm{l}$ of PCR mixture) were included in each PCR run to check for potential contamination and unspecific products. The PCR products were run on $1.0 \%$ agarose gels. The gel was stained with a working solution of SYBR Gold (Molecular Probes). The obtained bands were cut, purified by Quick gel extraction kit (Genscript), and quantified using a Nanodrop spectrophotometer. Fluorescently labelled PCR products were digested at $37^{\circ} \mathrm{C}$ overnight. Each reaction contained $30 \mathrm{ng}$ of cleaned PCR product, $5 \mathrm{U}$ of tetrameric restriction enzyme
(HhaI) and the respective buffer filled up to a final concentration of $50 \mu \mathrm{l}$ with ultrapure water (Sigma). The restriction enzyme was heat inactivated and precipitated by adding $4.5 \mu \mathrm{l}$ LPA solution and $100 \mu \mathrm{l} 100 \%$ isopropanol. The samples were stored at room temperature for $15 \mathrm{~min}$ and afterwards were centrifuged at $15000 \times g$ for $15 \mathrm{~min}$. After removing the supernatant, the pellets were rinsed with $100 \mu \mathrm{l} 70 \%$ isopropanol and precipitated again by centrifugation $(15000 \times g$ for $5 \mathrm{~min})$. Thereafter, the supernatant was removed, and the samples were dried in the cycler at $94^{\circ} \mathrm{C}$ for $1 \mathrm{~min}$ and stored at $-20^{\circ} \mathrm{C}$.

The pellet was resuspended in $2 \mu$ of ultraclean water (Sigma), and the product was denatured in $7.8 \mu \mathrm{l}$ of Hi-Di formamide at $94^{\circ} \mathrm{C}$ for $3 \mathrm{~min}$. Each sample contained $0.2 \mu \mathrm{l}$ GeneTrace 1000 (ROX) marker (Applied Biosystems). Fluorescently labelled fragments were detected and separated with an ABI Prism 310 capillary sequencer (Applied Biosystem) run under GeneScan mode (van der Maarel et al. 1998, Moeseneder et al. 1999). The size of the fluorescently labelled fragments was determined by comparison with the internal GeneTrace 1000 (ROX) size standard. Injection was performed electrokinetically at $15 \mathrm{kV}$ for $15 \mathrm{~s}$ (adjustable), and the runs were completed at $15 \mathrm{kV}$ and $60^{\circ} \mathrm{C}$ within $35 \mathrm{~min}$.

Automated rRNA intergenic spacer analysis (ARISA). ARISA-PCR was performed following the method of Borneman \& Triplett (1997) with modifications. One microlitre of the DNA extract was used as a template in a $50 \mu \mathrm{l}$ PCR mixture. The primers used were ITSf, 5'-GTC GTA ACA AGG TAG GCC GTA-3', and ITSr eub, 5'-GCC AAG GCA TCC ACC-3'. The primer ITSf was end-labelled with the phosphoramidite dye 5-FAM. Samples were amplified by an initial denaturation step at $94^{\circ} \mathrm{C}$ for $2 \mathrm{~min}$, followed by 30 cycles of amplification at $94^{\circ} \mathrm{C}$ for $15 \mathrm{~s}, 55^{\circ} \mathrm{C}$ for $30 \mathrm{~s}$ and $72^{\circ} \mathrm{C}$ for $3 \mathrm{~min}$, and a final extension at $72^{\circ} \mathrm{C}$ for $9 \mathrm{~min}$. As for T-RFLP, 2 negative controls were included in each PCR run to check for potential contamination and unspecific products. Five microlitres of PCR products were run on a $2.0 \%$ agarose gel for quality assessment of the products. The gel was stained with a working solution of ethidium bromide. The PCR products were purified with Quick Clean PCR product purification kit (Genscript) and quantified using a Nanodrop spectrophotometer. Fluorescently labelled fragments ( $8 \mathrm{ng} \mathrm{\mu l}^{-1}$ of sample) were separated and detected with an ABI Prism 310 capillary sequencer (Applied Biosystem) run under GeneScan mode. The size of the fluorescently labelled fragment was determined by comparison with the combination of the internal GeneTrace 1000 (ROX), CST 300-1800 and the size standard. Injection was performed electrokinetically at $10 \mathrm{kV}$ for $5 \mathrm{~s}$ (adjustable), and the run was completed at $60^{\circ} \mathrm{C}$ within $60 \mathrm{~min}$. 
The output of T-RFLP and ARISA from the ABI Genescan software was transferred to the Fingerprinting II software (Bio-Rad) to determine peaks and to standardize the peaks with the size marker. The threshold of peaks was set to $0.1 \%$ of the maximum peak height per run. Peaks above the $0.1 \%$ threshold were defined as operational taxonomic units (OTUs) and were used for further analysis.

Statistical analyses. Presence/absence patterns of OTUs of individual samples determined by both T-RFLP and ARISA were further analyzed using the Primer software (Primer-E) to determine the Jaccard similarity. To compare the similarity matrices of prokaryotic communities collected at different sites or depths, the Mantel test was used (Paleontological Statistics [PAST] Ver. 1.75).

\section{RESULTS}

\section{Environmental parameters}

There was little variability in temperature and salinity among the 5 stations (Table 1). The temperature difference between surface and deep waters was relatively small, with a maximum range of 20.35 to $13.36^{\circ} \mathrm{C}$. Phosphate and nitrate concentrations exhibited a common depth-related trend, with low concentrations in the top $100 \mathrm{~m}$ layer and increasing with depth (Table 1). Oxygen concentrations remained rather constant, with depth exhibiting no pronounced oxygen minimum layer below the euphotic layer.

\section{Depth distribution patterns of prokaryotic variables}

Prokaryotic abundance (PA) ranged from $2.5 \times 10^{5}$ to $5.0 \times 10^{5}$ cells ml ${ }^{-1}$ in the surface layer, and decreased exponentially with depth to $0.2 \times 10^{5}$ cells $\mathrm{ml}^{-1}$ at $3000 \mathrm{~m}$ depth (Fig. 2A). The depth-dependent decrease of PA was described by a log-log linear regression with a slope of $-0.65 \pm 0.23(n=5)$ (Table 2).

Prokaryotic leucine incorporation (leu incorp.) decreased by 1 order of magnitude from surface waters (97.3 pmol leu incorp. $\mathrm{l}^{-1} \mathrm{~h}^{-1}$ ) to the mesopelagic layer (Fig. 2B). The depth distribution patterns of prokaryotic leu incorp., however, were less pronounced than those for PA and were variable among stations. All the depth profiles of leu incorp. showed, after a decline from the $10 \mathrm{~m}$ layer to the $100 \mathrm{~m}$ layer, a peak in the mesopelagic layer (200 to $1000 \mathrm{~m})$, varying, however, among stations. Significant depth-dependent decreases (log-log linear regression) were only found at Stn 1 and Stn 4 (Table 2).

Cell-specific activity (prokaryotic leu incorp. divided by PA) exhibited a depth-related trend only in the euphotic layer, but not in upper mesopelagic to bathypelagic waters (Fig. 2C). Maximum cell-specific activity was $6.3 \times 10^{-3} \mathrm{fmol} \mathrm{leu} \mathrm{cell}{ }^{-1} \mathrm{~d}^{-1}$ at $50 \mathrm{~m}$ depth at Stn 3 (Fig. 2C). Generally, cell-specific activity was more variable in meso- and bathypelagic layers than in the surface layer. In meso- and bathypelagic layers, the minimum cell-specific activity was $5.5 \times 10^{-5} \mathrm{fmol}$ cell ${ }^{-1} \mathrm{~d}^{-1}$ at $750 \mathrm{~m}$ depth at Stn 4, and the highest was $2.4 \times 10^{-3} \mathrm{fmol} \mathrm{cell}^{-1} \mathrm{~d}^{-1}$ at $750 \mathrm{~m}$ depth at Stn 5. Overall, the cell-specific activity in the meso- and bathypelagic waters was within 1 order of magnitude, with only a few exceptions (Fig. 2C).

\section{Bacterial community composition analyzed by T-RFLP and ARISA}

The T-RFLP pattern of the bacterial community revealed in total 63 OTUs on the 16S rRNA gene level, ranging from 12 to 22 OTUs sample ${ }^{-1}$, whereas the

Table 1. Physical and chemical characteristics of the stations sampled during the cruise in the eastern Mediterranean Sea. Data for the euphotic layer $(<100 \mathrm{~m}$ depth) correspond to the values for each sample. Mean \pm SD are given for meso- and bathypelagic waters

\begin{tabular}{|c|c|c|c|c|c|c|c|c|c|c|}
\hline Stn & Region & $\begin{array}{c}\text { Bottom } \\
\text { depth (m) }\end{array}$ & $\begin{array}{l}\text { Layer } \\
\text { (m) }\end{array}$ & $\begin{array}{c}\text { No. of } \\
\text { samples }\end{array}$ & $\begin{array}{c}\text { Temperature } \\
\left({ }^{\circ} \mathrm{C}\right)\end{array}$ & Salinity & $\begin{array}{c}\text { Dissolved } \\
\text { oxygen } \\
\left(\mu \mathrm{mol} \mathrm{l}^{-1}\right)\end{array}$ & $\begin{array}{c}\mathrm{PO}_{4} \\
\left(\mu \mathrm{mol} \mathrm{l}^{-1}\right)\end{array}$ & $\begin{array}{c}\mathrm{NO}_{3} \\
\left(\mu \mathrm{mol} \mathrm{l} l^{-1}\right)\end{array}$ & $\begin{array}{c}\mathrm{NO}_{2} \\
\left(\mu \mathrm{mol} \mathrm{l}{ }^{-1}\right)\end{array}$ \\
\hline \multirow[t]{2}{*}{1} & North & 1010 & $<100$ & 2 & $14.31,16.18$ & $36.73,38.45$ & $129.8,133.6$ & $0.04,0.05$ & $0.36,0.68$ & $0.05,0.10$ \\
\hline & Aegean & & $100-950$ & 6 & $13.84 \pm 0.40$ & $38.99 \pm 0.04$ & $124.2 \pm 4.6$ & $0.12 \pm 0.04$ & $3.10 \pm 1.29$ & $0.05 \pm 0.01$ \\
\hline \multirow[t]{2}{*}{2} & Mid- & 800 & $<100$ & 2 & $15.54,16.60$ & $39.16,40.00$ & $109.6,141.9$ & 0.02 & $0.07,0.13$ & 0.05 \\
\hline & Aegean & & $100-750$ & 7 & $14.38 \pm 0.30$ & $39.01 \pm 0.05$ & $132.6 \pm 3.2$ & $0.07 \pm 0.02$ & $1.76 \pm 0.53$ & $0.05 \pm 0.01$ \\
\hline \multirow[t]{2}{*}{3} & Western & 1245 & $<100$ & 2 & $15.00,17.82$ & $38.79,38.82$ & 137.5 & 0.03 & $0.12,0.41$ & $0.04,0.08$ \\
\hline & Cretan & & $100-1200$ & 7 & $14.45 \pm 0.15$ & $38.94 \pm 0.03$ & $130.1 \pm 2.3$ & $0.10 \pm 0.04$ & $2.56 \pm 1.06$ & $0.05 \pm 0.01$ \\
\hline \multirow[t]{3}{*}{4} & Ionian & 4322 & $<100$ & 2 & $16.85,19.92$ & $38.67,38.65$ & $137.3,147.0$ & $0.02,0.03$ & $0.03,0.06$ & $0.04,0.05$ \\
\hline & & & $100-1000$ & 7 & $14.86 \pm 0.81$ & $38.81 \pm 0.06$ & $129.9 \pm 11.0$ & $0.09 \pm 0.07$ & $1.76 \pm 1.54$ & $0.04 \pm 0.01$ \\
\hline & & & $2000-4350$ & 3 & $14.60 \pm 0.78$ & $38.75 \pm 0.01$ & $123.0 \pm 1.3$ & $0.15 \pm 0.01$ & $3.57 \pm 0.45$ & $0.04 \pm 0.01$ \\
\hline \multirow[t]{2}{*}{5} & South & 1420 & $<100$ & 2 & $15.63,20.35$ & $35.98,39.20$ & $117.6,152.3$ & 0.03 & $0.07,0.33$ & $0.05,0.08$ \\
\hline & Aegean & & $100-1350$ & 7 & $14.68 \pm 0.52$ & $39.00 \pm 0.06$ & $137.2 \pm 4.7$ & $0.10 \pm 0.04$ & $2.52 \pm 1.26$ & $0.07 \pm 0.06$ \\
\hline
\end{tabular}



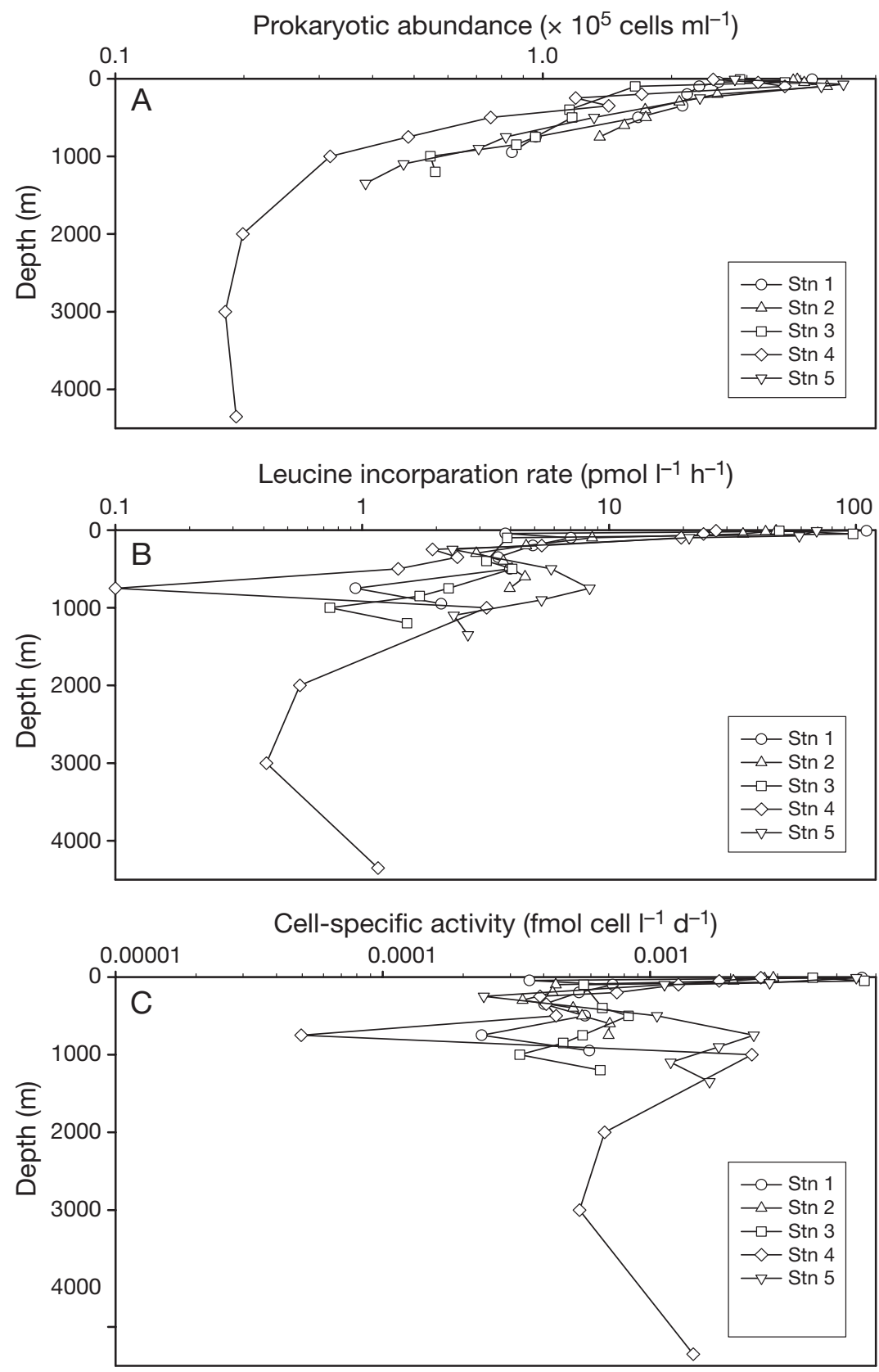

Fig. 2. Depth profiles of (A) prokaryotic abundance, (B) leucine incorporation rate, and (C) specific leucine incorporation rate

$\pm 4 \%(\mathrm{n}=28)$ for T-RFLP and ARISA, respectively, of the total number of OTUs (sum of all OTUs detected). Two OTUs out of 63 determined by T-RFLP analysis were ubiquitously present (at all stations and depths), while only 1 OTU in ARISA analysis was ubiquitously present. The number of unique OTUs was 11 and 39 for T-RFLP and ARISA, respectively. These unique OTUs (i.e. appearing only once in all the samples) were evenly distributed among depths and stations (data not shown).

Although the number of OTUs did not follow a specific depth-related pattern, similarity analysis of the BCC on both the 16S rRNA gene and the ITS level indicated stratification of the BCC with depth. On the 16S rRNA gene level, 3 major clusters were identified (Fig. 4A): a bathypelagic cluster (3000 to $4000 \mathrm{~m}$ depth), a mesopelagic cluster (200 to $1400 \mathrm{~m}$ depth) and a deep mesopelagic cluster (500 to $945 \mathrm{~m}$ depth). At Stn 5, a single cluster was detected for the community between 250 and $1400 \mathrm{~m}$ depth (Fig. 4A). On the ITS level, 4 clusters were identified (Fig. 4B). One cluster comprised the surface samples from 45 to $250 \mathrm{~m}$ depth, 2 clusters were identified for bathypelagic waters, and 1 was identified for mesopelagic waters. The average percentage of similarity among the samples was $49 \pm 14$ and $28 \pm$ $21 \%$ for T-RFLP and ARISA, respectively. The similarity matrices of the BCC based on the 16S rRNA gene level and on the ITS level were significantly correlated (Mantel test, $\mathrm{r}=0.69, \mathrm{p}<0.001$ ).

\section{Bacterial community composition in specific water masses}

To determine whether the BCC is

ARISA pattern of the bacterial community revealed in total 169 OTUs on the internal transcribed spacer (ITS) level, ranging from 16 to 45 OTUs sample ${ }^{-1}$. Thus, ARISA resulted in an almost 3-fold higher resolution for the bacterial community than T-RFLP and 16S rRNA gene analysis.

Generally, the number of OTUs in both T-RFLP and ARISA were fairly constant throughout the water column (Fig. 3). The mean percentage of OTUs present in a given sample was $26 \pm 4 \%$ (average $\pm \mathrm{SD}, \mathrm{n}=27$ ) and 16 water mass specific, we determined the relationship between the similarity of the BCC among several samples with the hydrographic similarity of these water masses. As an indicator of the hydrographic similarity of the different water masses, we calculated the Euclidean distance between 2 water samples on the temperature-salinity (T-S) diagram. We coined this ' $\mathrm{T}-\mathrm{S}$ distance' to be a parameter of water mass similarity. Fig. 5 shows the relationships between the similarity of the BCC and the T-S dis- 
Table 2. Values at $100 \mathrm{~m}$ and regression results of the decline of prokaryotic abundance (PA) and leucine incorporation rate (leu incorp.) with depth (>100 m depth). The model used was $N=N_{100} \times(Z / 100)^{b}$, where $N$ and $Z$ are either PA or leu incorp. and depth (m), respectively. $N_{100}$ is the value of the specific parameter at $100 \mathrm{~m} \mathrm{depth}$, and $b$ is the log-log slope of the depth-dependent decline of $N$, which was estimated by the linear regression of $\log N$ on $\log Z$. $t$-tests were performed for the datasets of the Atlantic

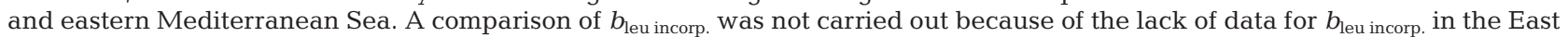

Mediterranean Sea. * : significant difference $(p<0.01)$ between the parameter in the Atlantic and East Mediterranean Sea

\begin{tabular}{|c|c|c|c|c|}
\hline & \multicolumn{2}{|c|}{ Prokaryotic abundance } & \multicolumn{2}{|c|}{ Leucine incorporation rate } \\
\hline & $\left.\begin{array}{c}\mathrm{PA}_{100} \\
\left(\times 10^{5} \text { cells ml }\right. \\
-1\end{array}\right)$ & $b_{\mathrm{PA}}$ & $\begin{array}{l}\text { Leu incorp.100 } \\
\left(\mathrm{pmol} \mathrm{l}^{-1} \mathrm{~h}^{-1}\right)\end{array}$ & $b_{\text {leu incorp. }}$ \\
\hline $\begin{array}{l}\text { East Mediterranean Sea } \\
\text { (Present study) }\end{array}$ & $\begin{array}{c}3.35 \pm 1.32 \\
(\mathrm{n}=5)\end{array}$ & $\begin{array}{c}-0.65 \pm 0.23 \\
(\mathrm{n}=5)\end{array}$ & $\begin{array}{c}12.03 \pm 7.82^{*} \\
\quad(\mathrm{n}=5)\end{array}$ & $\begin{array}{l}-0.78,-0.70 \\
\quad(\mathrm{n}=2)^{\mathrm{a}}\end{array}$ \\
\hline $\begin{array}{l}\text { Atlantic (G. J. Herndl \& } \\
\text { T. Reinthaler unpubl. data) }\end{array}$ & $\begin{array}{l}3.03 \pm 0.54 \\
(\mathrm{n}=27)\end{array}$ & $\begin{array}{l}-0.79 \pm 0.35 \\
(\mathrm{n}=27)\end{array}$ & $\begin{array}{l}3.40 \pm 2.27^{*} \\
(\mathrm{n}=22)\end{array}$ & $\begin{array}{l}-1.61 \pm 0.38 \\
\quad(\mathrm{n}=22)\end{array}$ \\
\hline $\begin{array}{l}\text { NW Mediterranean Sea } \\
\text { (Tanaka \& Rassoulzadegan 2004) }\end{array}$ & - & $\begin{array}{c}-0.62 \pm 0.18 \\
(\mathrm{n}=11)\end{array}$ & - & $\begin{array}{l}-1.15 \pm 0.30 \\
\quad(\mathrm{n}=5)\end{array}$ \\
\hline
\end{tabular}

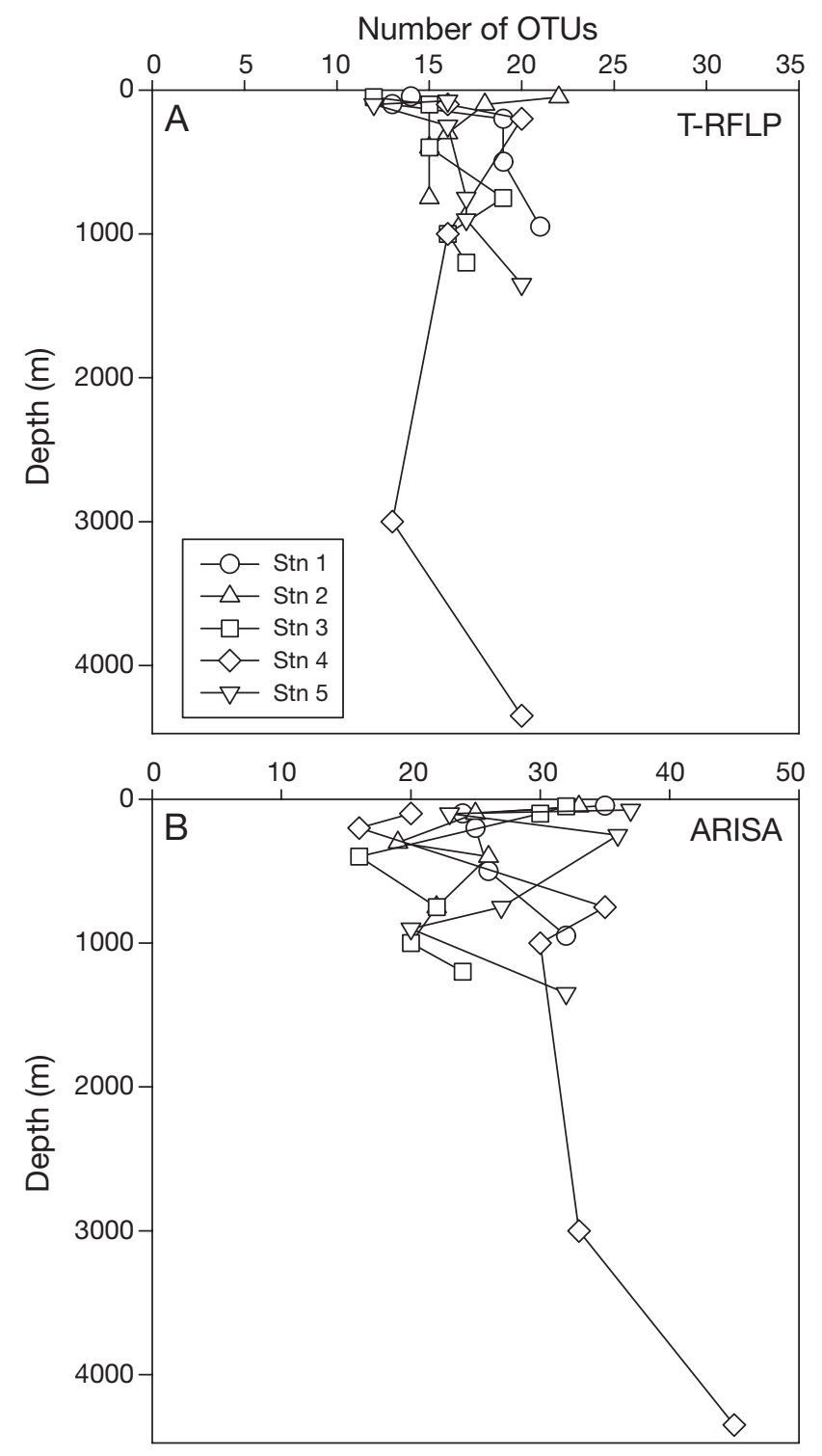

tance of water masses. The relations between $\mathrm{T}-\mathrm{S}$ distance and the similarities of the BCC determined by T-RFLP and ARISA showed similar distribution patterns (Fig. 5A,B). Although there was no significant relation between the similarity in the BCC and $\mathrm{T}-\mathrm{S}$ distance (Mantel test, $\mathrm{p}>0.05$ ), distinct patterns in the $\mathrm{BCC}$ related to $\mathrm{T}-\mathrm{S}$ distance were noticeable. The similarity in the BCC between samples decreased with increasing $\mathrm{T}-\mathrm{S}$ distance of the corresponding waters. Low similarity values of the BCC, however, were obtained at all $\mathrm{T}-\mathrm{S}$ distances, indicating that even in samples with essentially the same T-S signature, the BCC can be very different.

\section{DISCUSSION}

We found 2 overall patterns in the relation between the BCC and water mass variability as indicated by their T-S distance (Fig. 5A,B). While overall, the similarity of the BCC decreased in waters with increasing $\mathrm{T}-\mathrm{S}$ distance, low similarity in the BCC was also found between samples with essentially identical T-S signatures (Fig. 5A,B). Previous studies showed decreasing similarity in the BCC with spatial distance on a 'hundreds-thousands km scale' (Hewson et al. 2006a,b) and on a 'latitudinal scale' (Fuhrman et al. 2008). Our results reveal that substantial heterogeneity in the BCC can also be found within water masses as indicated by identical T-S signatures.

Fig. 3. Distribution of the number of operational taxonomic units (OTUs) obtained at the stations in the eastern Mediterranean Sea by (A) terminal-restriction-fragment length polymorphism (T-RFLP) and (B) automated rRNA intergenic spacer analysis (ARISA) 

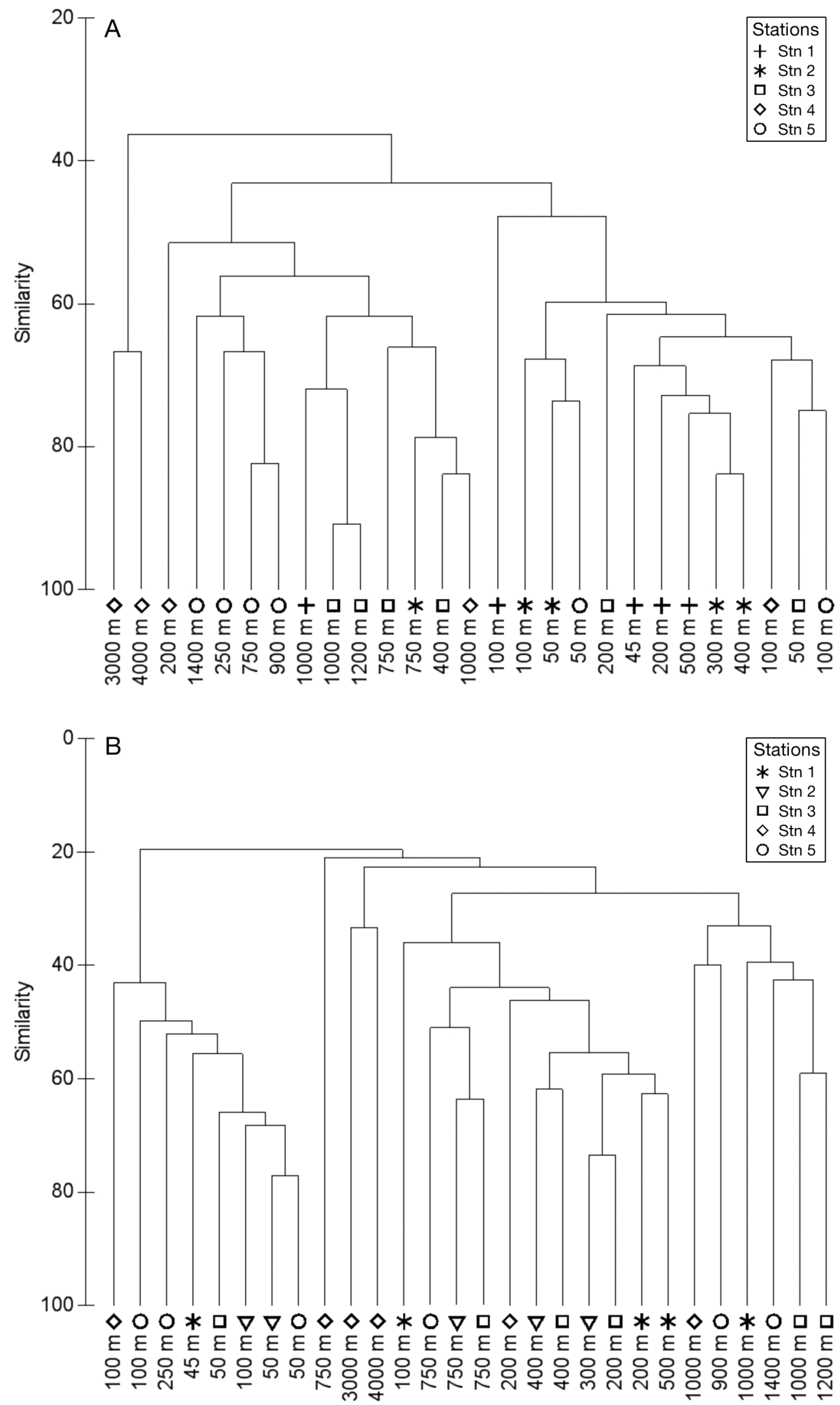

Fig. 4. Similarity matrix for the individual samples determined by (A) terminal-restriction-fragment length polymorphism (T-RFLP) and (B) automated rRNA intergenic spacer analysis (ARISA) in the eastern Mediterranean Sea 

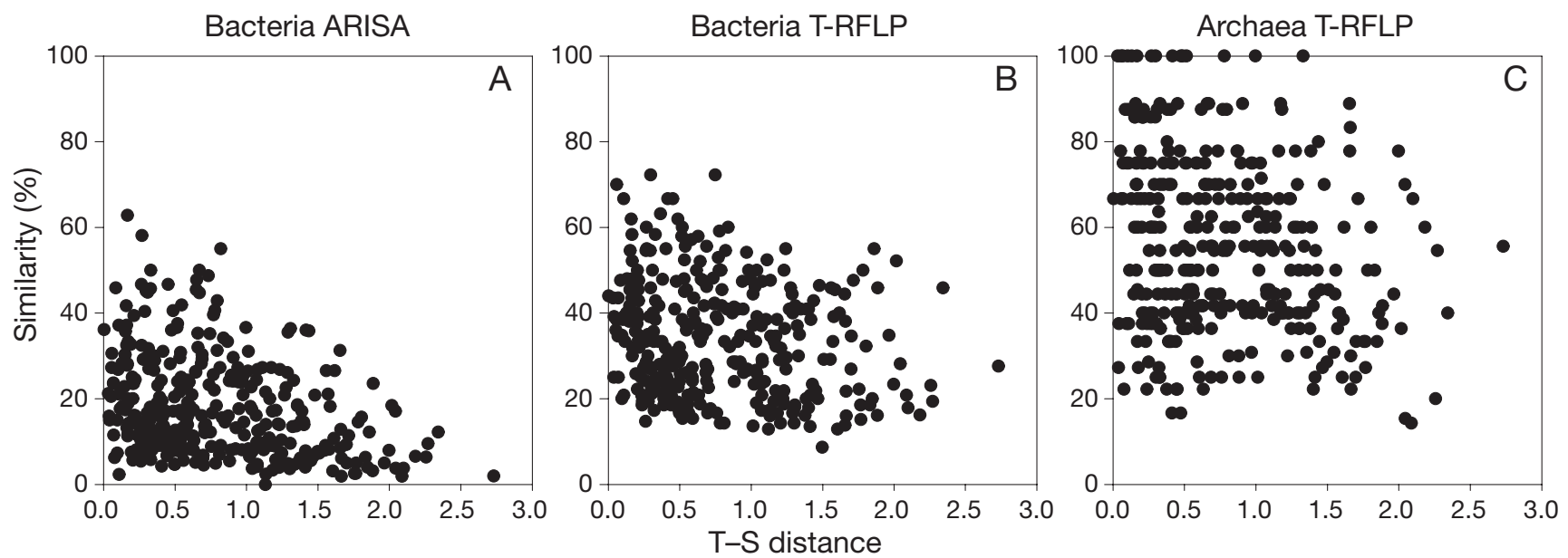

Fig. 5. Relationship between temperature-salinity (T-S) distance of 2 water masses and the similarity of the bacterial community composition in these water masses determined by (A) ARISA and (B) T-RFLP. (C) The similarity of the archaeal community composition determined by T-RFLP is also given for comparison (data from De Corte et al. 2009)

\section{Distribution pattern of prokaryotic abundance and activity}

The depth profiles of prokaryotic abundance measured in the present study are comparable to those in previous studies of the Atlantic (data from the ARCHIMEDES I cruise; G. J. Herndl \& T. Reinthaler unpubl. data) and the northwestern Mediterranean Sea (Tanaka \& Rassoulzadegan 2004). There are no significant differences in prokaryotic abundance at $100 \mathrm{~m}$ depth between the Atlantic and the eastern Mediterranean Sea and in the depth-dependent decline of abundance (Table 2). Remarkable differences were found, however, in terms of prokaryotic heterotrophic activity between the present study and the Atlantic study. Depth-dependent decreases of prokaryotic activity were only detected in 2 out of the 5 stations in the current study (Fig. 2B), while in the North Atlantic and the northwestern Mediterranean Sea almost all profiles exhibit a depth-dependent decrease (Tanaka \& Rassoulzadegan 2004, G. J. Herndl \& T. Reinthaler unpubl. data). Cell-specific activity in the mesopelagic layer was similar to that for surface waters (Fig. 2C), suggesting that some populations of prokaryotes are as active in mesopelagic waters as in surface waters. High cell-specific activity in mesopelagic waters seems to be a common feature, also reported in a recent compilation of data from deep waters (Arístegui et al. 2009). These results indicate that the overall decrease in bulk prokaryotic activity with depth is caused by a decrease in the active prokaryotic populations rather than by an overall decrease in cell-specific activity.

Several factors have been reported to limit heterotrophic prokaryotic activity. Studies revealed that prokaryotic activity reflects availability of usable organic matter (Church 2008), temperature (Kirchman \& Rich 1997) and inorganic nutrients (Turley \& Stutt 2000). We found that sporadic low prokaryotic activities at $750 \mathrm{~m}$ depth of Stn 1, at $1000 \mathrm{~m}$ depth of Stn 3 and at $750 \mathrm{~m}$ depth of Stn 4 correspond to aged water masses (Zervakis et al. 2004). This distribution pattern of prokaryotic production in the eastern Mediterranean Sea may be partly explained by the patchiness of resources for heterotrophic bacteria because of the isolated deep-water masses in each basin of the eastern Mediterranean Sea. The isolated deep-water masses have their own unique dissolved organic matter signature (Meador et al. in press).

To determine the environmental factors controlling prokaryotes, regression analyses were performed between prokaryotic variables (abundance, activity, cell-specific activity) and environmental variables (temperature, salinity, depth). A significant linear regression was found only between the prokaryotic leu incorp. rate and temperature. Within the small range of water temperature (13.4 to $\left.20.4^{\circ} \mathrm{C}\right)$, heterotrophic prokaryotic activity measured via leu incorp. was explained by temperature, as described by the following equation:

$$
\begin{aligned}
& \mathrm{PLI}_{\text {EastMedSea }}=4.78 T-64.67 \\
& \left(\mathrm{r}^{2}=0.37, \mathrm{p}<0.001, \mathrm{n}=30\right)
\end{aligned}
$$

where $\mathrm{PLI}_{\text {EastMedSea }}$ and $T$ are the prokaryotic leu incorp. rate (pmol leu $\mathrm{l}^{-1} \mathrm{~h}^{-1}$ ) and temperature $\left({ }^{\circ} \mathrm{C}\right)$, respectively. A temperature-dependent increase in the prokaryotic leu incorp. rate was also found elsewhere, e.g., in the North Atlantic (G. J. Herndl \& T. Reinthaler unpubl. data), such that: 


$$
\begin{aligned}
& \mathrm{PLI}_{\text {NorthAtlantic }}=0.18 T-0.94 \\
& \left(\mathrm{r}^{2}=0.51, \mathrm{p}<0.001, \mathrm{n}=130\right)
\end{aligned}
$$

The relation between temperature and leu incorp. for the eastern Mediterranean Sea, however, might not be a direct effect of temperature on prokaryotic activity, as this temperature dependency is substantially higher than in the North Atlantic (i.e. 26-fold higher than in the Atlantic), but might be explained by some variables co-varying with temperature such as depth. Resource limitation with depth might be more pronounced in the eastern Mediterranean Sea than in other parts of the global ocean, due to the severe oligotrophic nature of this region. Furthermore, to examine both water temperature and depth potentially affecting leu incorp., a forward stepwise regression analysis was conducted. In the North Atlantic (G. J. Herndl \& T. Reinthaler unpubl. data) both factors, water temperature and depth, were selected as significant predicting variables ( $p<0.001)$, whereas, in the eastern Mediterranean Sea, the forward stepwise regression analysis did not select depth as a significant predicting factor $(p=0.27)$, but did select temperature $(p<0.001)$.

To compare the strength of 'top-down control' in the eastern Mediterranean Sea compared to other oceanic regions, we assumed that a shorter turnover time at a similar prokaryotic abundance as in other oceanic regions indicates top-down control, mediated by grazing or viral infection. To determine the turnover time of prokaryotes, the following equation was used:

$$
T=\mathrm{PA} /(f \times \mathrm{PHP})
$$

where $T$ is turnover time (days), PA is prokaryotic abundance (cells ml-1), $f$ is the conversion factor $\left(\mathrm{mol}^{3} \mathrm{H}\right.$-leu incorp. to cells produced: $1.64 \times 10^{17}$ cells mol $^{-1}$ leu incorp.; Chin-Leo \& Kirchman 1988), PHP is prokaryotic heterotrophic production (pmol leu $\mathrm{l}^{-1} \mathrm{~d}^{-1}$ ). The mean turnover time in the present study was $11 \pm 18 \mathrm{~d}$ (range: 1.0 to $123, \mathrm{n}=49$ ). Prokaryotic turnover time in the eastern Mediterranean Sea is substantially shorter than in the NW Mediterranean Sea $(81 \pm 32 d$; Tanaka \& Rassoulzadegan 2004), in the North Atlantic $(18 \pm 70 \mathrm{~d}$; Fig. 8 in Reinthaler et al. 2006) and in the Pacific (1155 \pm 1803 d; Nagata et al. 2000) over the same depth range. Prokaryotic abundance in the eastern Mediterranean Sea, however, is comparable to that in other oceanic regions (Table 2). Thus, there is indication that prokaryotic communities are more 'top-down' controlled in the eastern Mediterranean Sea than in other oceanic regions.

\section{Variability in bacterial community composition}

The total number of OTUs determined by ARISA was higher than with T-RFLP. This is because the ITS region used for ARISA is more variable than the $16 \mathrm{~S}$ rRNA gene used for T-RFLP (Brown \& Fuhrman 2005). In similar studies, slightly higher total numbers of OTUs have been obtained with ARISA (Hewson et al. 2006a, Fuhrman et al. 2008) and with T-RFLP (Moeseneder et al. 2001b, Winter et al. 2008). Moeseneder et al. (2001b) determined for March 1998 both the attached and free-living bacterial community in the same region as covered in the present study. These authors report numbers of OTUs using T-RFLP ranging between 20 and 65, while we obtained a range of OTUs from 12 to 22 (Fig. 4). Differences in the number of OTUs between our study and others can be explained by seasonal dynamics in OTU numbers (Fuhrman et al. 2006) or, more likely, by the different restriction enzymes used. The number of OTUs did not correlate with any prokaryotic variables ( $p>0.05)$. This means that bacterial OTU numbers are not related to prokaryotic abundance and activity, at least not in the range of activity we measured.

T-RFLP analysis revealed that the BCC at the 5 stations displayed a distinct depth-related pattern (Fig. 4A). A parallel analysis based on ARISA also revealed the same trend as the T-RFLP analysis (Fig. 4B). This means that OTUs, which are distinguished on the ITS and 16S rDNA levels, respond in the same manner to environmental variables. Albeit a few ubiquitously present OTUs were detected (data not shown), drastic changes in the BCC were noted with depth. A stratification of the prokaryotic community composition has been reported for the bulk prokaryotic community elsewhere, such as for the deep Pacific (DeLong et al. 2006) and the NW Mediterranean Sea (Winter et al. 2009). This suggests that the factors controlling the BCC are related to depth. Sedimenting particulate organic matter supply and its nutritive value decrease with depth, exerting a structuring effect on the BCC (Moeseneder et al. 2001b). Hydrostatic pressure might also affect the stratification of bacterial communities (Grossart \& Gust 2009).

Stratification of community composition was also found in Archaea (De Corte et al. 2009) for the same sites as investigated here. Statistical analysis showed that the similarity of the archaeal community composition between sites and depths is related to the similarity in the BCC determined by both T-RFLP (Mantel test, $\mathrm{r}=0.4671, \mathrm{p}<0.001$ ) and ARISA (Mantel test, $\mathrm{r}=$ 0.5617, $\mathrm{p}<0.001)$. This indicates that the archaeal community composition and BCC are structured by similar environmental variables.

Our study also revealed considerable variability in the BCC in waters with identical temperature and salinity. Similarities in the BCC in waters with identical or similar temperature and salinity characteristics (i.e. $\mathrm{T}-\mathrm{S}$ distance $=0$ or close to 0 ) varied from near 0 to the 
highest similarity detected for any of the sample pairs (Fig. 5A,B). This indicates that factors controlling the $\mathrm{BCC}$ vary also within individual water masses. Previous studies have revealed that the BCC can vary on a small scale, such as in diatom blooms developing in mesocosms (Riemann et al. 2000). On a micro-scale down to $1 \mu \mathrm{l}$ of water, changes in the $\mathrm{BCC}$ have been documented (Long \& Azam 2001). This small-scale variability in the $\mathrm{BCC}$ or that within waters with identical salinity and temperature characteristics might be generated by heterogeneity of substrate compositions. Hotspots of organic matter (Azam et al. 1994), such as sinking particulate organic carbon plumes (Kiorboe et al. 2001), marine snow (Simon et al. 2002) and release of dissolved organic matter by Protozoa (Ferrier-Pages et al. 1998), or self assemblage of organic compounds to gels (Chin et al. 1998) might generate such withinwater mass variability and associated to that, variability in the BCC. Top-down factors might also generate heterogeneity, because the strength of the link between prokaryotes and heterotrophic nanoflagellates varies with depth (Tanaka \& Rassoulzadegan 2002, Tanaka et al. 2005). Archeal community composition determined by T-RFLP (data from De Corte et al. 2009), however, did not show any trend with T-S distance of water masses (Fig. 5C). This might indicate that differences in hydrological conditions affected the archaeal community composition to a lesser extend than bacteria.

In the present study we used temperature and salinity, commonly determined to identify water masses, as an index to determine the 'hydrological distance' among samples. This ' $\mathrm{T}-\mathrm{S}$ distance' is preferable to the simple spatial distance frequently used, as specific water masses are highly variable in their extension, ranging from a few hundred meters in vertical or areal extension to thousands of kilometres in oceanic conveyor belt circulation. Hence, simple spatial distance does not necessarily relate to differences in water column biogeochemistry and biology. Based on the relation between the $\mathrm{BCC}$ and $\mathrm{T}-\mathrm{S}$ distance, the $\mathrm{BCC}$ varies within individual water mass conditions as much as between distant water masses. Overall, however, the similarity in the BCC decreased with distance in $\mathrm{T}-\mathrm{S}$. Thus, the overall change in similarity of bacterial communities with distance in a given water mass is superimposed over the variability generated apparently by small-scale patchiness in the water column.

Acknowledgements. We thank A. Gogou (HCMR) and G. Spyres (HCMR) for all the logistic arrangements before and during the cruise, the captain and crew of the RV 'Aegaeo' for their help at sea. T. Miki (NTU) provided comments on the manuscript. S. Saraiva (NIOZ) made a script for calculation of 'T-S distance'. T.Y. was supported by the Japanese Society for the Promotion of Science (JSPS) Postdoctoral Fellowship for research abroad, and D.D.C. received a fellowship from the University of Groningen. Laboratory work and molecular analyses were supported by a grant from the Earth and Life Science Division of the Dutch Science Foundation (ARCHIMEDES project, 835.20.023) to G.J.H. The work was carried out within the frame of the 'Networks of Excellence' MarBef and EurOceans supported by the 6th Framework Program of the European Union.

\section{LITERATURE CITED}

Arístegui J, Gasol JM, Duarte CM, Herndl GJ (2009) Microbial oceanography of the dark ocean's pelagic realm. Limnol Oceanogr 54:1501-1529

Azam F, Smith DC, Steward GF, Hagström Å (1994) Bacteriaorganic matter coupling and its significance for oceanic carbon cycling. Microb Ecol 28:167-179

Borneman J, Triplett EW (1997) Molecular microbial diversity in soils from eastern Amazonia: evidence for unusual microorganisms and microbial population shifts associated with deforestation. Appl Environ Microbiol 63: 2647-2653

> Brown MV, Fuhrman JA (2005) Marine bacterial microdiversity as revealed by internal transcribed spacer analysis. Aquat Microb Ecol 41:15-23

Chin WC, Orellana MV, Verdugo P (1998) Spontaneous assembly of marine dissolved organic matter into polymer gels. Nature 391:568-572

Chin-Leo G, Kirchman DL (1988) Estimating bacterial production in marine waters from the simultaneous incorporation of thymidine and leucine. Appl Environ Microbiol 54:1934-1939

Church MJ (2008) Resource control of bacterial dynamics in the sea. In: Kirchman DL (ed) Microbial ecology of the oceans, 2nd edn. Wiley-Blackwell, London, p 335-382

> De Corte D, Yokokawa T, Varela MM, Agogue H, Herndl GJ (2009) Spatial distribution of bacteria and Archaea and amoA gene copy numbers throughout the water column of the eastern Mediterranean Sea. ISME J 3:147-158

DeLong EF, Preston CM, Mincer T, Rich V and others (2006) Community genomics among stratified microbial assemblages in the ocean's interior. Science 311:496-503

> Ferrier-Pages C, Karner M, Rassoulzadegan F (1998) Release of dissolved amino acids by flagellates and ciliates grazing on bacteria. Oceanol Acta 21:485-494

- Fuhrman JA (2009) Microbial community structure and its functional implications. Nature 459:193-199

Fuhrman JA, Hewson I, Schwalbach MS, Steel JA, Brown MV, Naeem S (2006) Annually reoccuring bacterial communities are predictable from ocean conditions. Proc Natl Acad Sci Usa 103:13104-13109

Fuhrman JA, Steele JA, Hewson I, Schwalbach MS, Brown MV, Green JL, Brown JH (2008) A latitudinal diversity gradient in planktonic marine bacteria. Proc Natl Acad Sci USA 105:7774-7778

Giovannoni SJ, Rappe MS, Vergin KL, Adair NL (1996) 16S rRNA genes reveal stratified open ocean bacterioplankton populations related to the green non-sulfur bacteria. Proc Natl Acad Sci USA 93:7979-7984

Grossart HP, Gust G (2009) Hydrostatic pressure affects physiology and community structure of marine bacteria during setting to $4000 \mathrm{~m}$ : an experimental approach. Mar Ecol Prog Ser 390:97-104

Hansell DA, Ducklow HW (2003) Bacterioplankton distribution and production in the bathypelagic ocean: Directly 
coupled to particulate organic carbon export? Limnol Oceanogr 48:150-156

Herndl GJ, Reinthaler T, Teira E, van Aken H, Veth C, Pernthaler A, Pernthaler J (2005) Contribution of Archaea to total prokaryotic production in the deep Atlantic Ocean. Appl Environ Microbiol 71:2303-2309

Hewson I, Steele JA, Capone DG, Fuhrman JA (2006a) Remarkable heterogeneity in meso- and bathypelagic bacterioplankton assemblage composition. Limnol Oceanogr 51:1274-1283

> Hewson I, Steele JA, Capone DG, Fuhrman JA (2006b) Temporal and spatial scales of variation in bacterioplankton assemblages of oligotrophic surface waters. Mar Ecol Prog Ser 311:67-77

Kiorboe T, Ploug H, Thygesen UH (2001) Fluid motion and solute distribution around sinking aggregates. I. Smallscale fluxes and heterogeneity of nutrients in the pelagic environment. Mar Ecol Prog Ser 211:1-13

Kirchman DL (2001) Measuring bacterial biomass production and growth rates from leucine incorporation in natural aquatic environments. In: Paul JH (ed) Methods in microbiology, Vol 30. Academic Press, New York, NY, p 227-237

Kirchman DL, Rich JH (1997) Regulation of bacterial growth rates by dissolved organic carbon and temperature in the equatorial Pacific Ocean. Microb Ecol 33:11-20

Lane DJ (1991) 16S/23S rRNA sequencing. In: Stackebrandt E, Goodfellow M (eds) Nucleic acid techniques in bacterial systematics. John Wiley \& Sons, New York, NY, p 115-176

Long RA, Azam F (2001) Microscale patchiness of bacterioplankton assmblage richness in seawater. Aquat Microb Ecol 26:103-113

Martín-Cuadrado AB, López-García P, Alba JC, Moreira D and others (2007) Metagenomics of the deep Mediterranean, a warm bathypelagic habit. PLoS ONE 2:e914 doi:10.1371/journal.pone.0000914

Meador TB, Gogou A, Spyres G, Herndl GJ and others (in press) Biogeochemical relationships between ultrafiltered dissolved organic matter and picoplankton activity in the eastern Mediterranean Sea. Deep-Sea Res II

Miki T, Yokokawa T, Nagata T, Yamamura N (2008) Immigration of prokaryotes to local environments enhances remineralization efficiency of sinking particles: a metacommunity model. Mar Ecol Prog Ser 366:1-14

> Moeseneder MM, Arrieta JM, Muyzer G, Winter C, Herndl GJ (1999) Optimization of terminal-restriction fragment length polymorphism analysis for complex marine bacterioplankton communities and comparison with denaturing gradient gel electrophoresis. Appl Environ Microbiol 65: 3518-3525

Moeseneder MM, Winter C, Arrieta JM, Herndl GJ (2001a) Terminal-restriction fragment length polymorphism ( $\mathrm{T}$ RFLP) screening of a marine archaeal clone library to determine the different phylotypes. J Microbiol Methods 44:159-172

Moeseneder MM, Winter C, Herndl GJ (2001b) Horizontal and vertical complexity of attached and free-living bacteria of the eastern Mediterranean Sea, determined by $16 \mathrm{~S}$ rDNA and 16S rRNA fingerprints. Limnol Oceanogr 46: 95-107

Moeseneder MM, Arrieta JM, Herndl GJ (2005) A comparison of DNA- and RNA-based clone libraries from the same marine bacterioplankton community. FEMS Microbiol Ecol 51:341-352

Nagata T, Fukuda H, Fukuda R, Koike I (2000) Bacterioplankton distribution and production in deep Pacific waters: large-scale geographic variations and possible coupling with sinking particle fluxes. Limnol Oceanogr 45:426-435

Reinthaler $\mathrm{T}$, van Aken $\mathrm{H}$, Veth $\mathrm{C}$, Aristegui $\mathrm{J}$ and others (2006) Prokaryotic respiration and production in the mesoand bathypelagic realm of the eastern and western North Atlantic basin. Limnol Oceanogr 51:1262-1273

> Riemann L, Steward GF, Azam F (2000) Dynamics of bacterial community composition and activity during a mesocosm diatom bloom. Appl Environ Microbiol 66:578-587

> Simon M, Grossart HP, Schweitzer B, Ploug H (2002) Microbial ecology of organic aggregates in aquatic ecosystems. Aquat Microb Ecol 28:175-211

Tanaka T, Rassoulzadegan F (2002) Full-depth profile $(0-2000 \mathrm{~m})$ of bacteria, heterotrophic nanoflagellates and ciliates in the NW Mediterranean Sea: vertical partitioning of microbial trophic structures. Deep-Sea Res I 49: 2093-2107

> Tanaka T, Rassoulzadegan F (2004) Vertical and seasonal variations of bacterial abundance and production in the mesopelagic layer of the NW Mediterranean Sea: bottomup and top-down controls. Deep-Sea Res I 51:531-544

Tanaka T, Rassoulzadegan F, Thingstad TF (2005) Analyzing the trophic link between the mesopelagic microbial loop and zooplankton from observed depth profiles of bacteria and protozoa. Biogeosciences 2:9-13

Turley CM, Stutt ED (2000) Depth-related cell-specific bacterial leucine incorporation rates on particles and its biogeochemical significance in the Northwest Mediterranean. Limnol Oceanogr 45:419-425

van der Maarel MJEC, Artz RRE, Haanstra R, Forney LJ (1998) Association of marine Archaea with the digestive tracts of two marine fish species. Appl Environ Microbiol 64:2894-2898

Varela MM, van Aken HM, Herndl GJ (2008) Abundance and activity of Chloroflexi-type SAR202 bacterioplankton in the meso- and bathypelagic waters of the (sub)tropical Atlantic. Environ Microbiol 10:1903-1911

Williams PJ le B (2000) Heterotrophic bacteria and the dynamics of dissolved organic material. In: Kirchman DL (ed) Microbial ecology of the oceans. Wiley-Liss, New York, NY, p 153-200

Winter C, Moeseneder MM, Herndl GJ, Weinbauer MG (2008) Relationship of geographic distance, depth, temperature, and viruses with prokaryotic communities in the eastern tropical Atlantic Ocean. Microb Ecol 56:383-389

Winter C, Kerros ME, Weinbauer MG (2009) Seasonal changes of bacterial and archaeal communities in the dark ocean: evidence from the Mediterranean Sea. Limnol Oceanogr 54:160-170

Yokokawa T, Nagata T (2010) Linking bacterial community structure to carbon fluxes in marine environments. J Oceanogr 66:1-12

Zervakis V, Georgopoulos D, Drakopoulos PG (2000) The role of the north Aegean in triggering the recent eastern Mediterranean climatic changes. J Geophys Res 105(C11):26103-26116

> Zervakis V, Georgopoulos D, Karageorgis AP, Theocharis A (2004) On the response of the Aegean Sea to climatic variability: a review. Int J Climatol 24:1845-1858 